\title{
Addendum: Editorial: Linking Ecosystem Function to Microbial Diversity
}

\author{
Anne E. Bernhard ${ }^{1 *}$ and John J. Kelly ${ }^{2}$ \\ ${ }^{1}$ Biology Department, Connecticut College, New London, CT, USA, ${ }^{2}$ Biology Department, Loyola University Chicago, \\ Chicago, IL, USA
}

Keywords: metatranscirptomics, permafrost, fungi, decomposition, diversity

\section{An addendum on}

Editorial: Linking Ecosystem Function to Microbial Diversity

by Bernhard, A. E., and Kelly, J. J. (2016). Front. Microbiol. 7:1041. doi: 10.3389/fmicb.2016.01041

Two additional papers that are featured in this Research Topic are published in Frontiers in

OPEN ACCESS

Edited and reviewed by: Lisa Y. Stein,

University of Alberta, Canada

*Correspondence:

Anne E. Bernhard

anne.bernhard@conncoll.edu

Specialty section:

This article was submitted to

Terrestrial Microbiology,

a section of the journal

Frontiers in Microbiology

Received: 05 August 2016 Accepted: 08 August 2016

Published: 22 August 2016

Citation:

Bernhard AE and Kelly JJ (2016)

Addendum: Editorial: Linking Ecosystem Function to Microbial Diversity. Front. Microbiol. 7:1299.

doi: 10.3389/fmicb.2016.01299
Terrestrial Microbiology. Valentin et al. (2014) explore relationships of fungal diversity and respiration rates of decomposing wood. And, using metatranscriptomics to investigate microbial activities in thawing permafrost, Coolen and Orsi (2015) demonstrate a potential link between bacteria carrying out acetogenesis and methanogenesis.

\section{AUTHOR CONTRIBUTIONS}

Both authors consulted on and drafted the commentary.

\section{REFERENCES}

Coolen, M. J. L., and Orsi, W. D. (2015). The transcriptional response of microbial communities in thawing Alaskan permafrost soils. Front. Microbiol. 6:197. doi: 10.3389/fmicb.2015.00197

Valentin, L., Rajala, T., Peltoniemi, M., Pannanen, T., Heinonsalo, J., and Mäkipää, R. (2014). Loss of diversity in woodinhabiting fungal communities affects decomposition activity in Norway spruce wood. Front. Microbiol. 5:230. doi: $10.3389 /$ fmicb.2014.00230

Conflict of Interest Statement: The authors declare that the research was conducted in the absence of any commercial or financial relationships that could be construed as a potential conflict of interest.

Copyright (๑) 2016 Bernhard and Kelly. This is an open-access article distributed under the terms of the Creative Commons Attribution License (CC BY). The use, distribution or reproduction in other forums is permitted, provided the original author(s) or licensor are credited and that the original publication in this journal is cited, in accordance with accepted academic practice. No use, distribution or reproduction is permitted which does not comply with these terms. 